\title{
Pengaruh Keluarga Broken terhadap Perilaku Penyimpangan Siswa di SMP Negeri 2 Plered
}

\author{
Nyai Maulidah \\ STAI DR. KHEZ. MUTTAQIEN \\ nyaimaulidah22@gmail.com
}

\author{
Abdurrahman Saleh \\ STAI DR. KHEZ. MUTTAQIEN
}

abayasmin81@gmail.com

DOI: https://DOI.org/10.52593/pdg.03.1.05

Naskah diterima:05 Januari 2022 direvisi: 28 Januari 2022 disetujui: 29 Januari 2022

\begin{abstract}
In the world of education, schools are not fully a determinant of the success of students, but the participation and encouragement of parents is a factor in achieving educational goals. The existence of the family is certainly the main point, a harmonious family will bring a comfortable, safe, peaceful and peaceful atmosphere in contrast to a less harmonious family which often occurs in disputes, fights, differences of opinion, to acts of violence, this will have the potential to be bad for the psychology and development of children. In this case, a broken family can be seen from two aspects, namely: (1) the family is divided because the structure is not intact because one of the heads of the family has died or has been divorced; (2) the parents are not divorced but the family structure is no longer intact because the father or mother is often not at home, and does not pay attention to affectionate relationships anymore. The impact of these factors is that children who come from broken home families will be very vulnerable to committing deviant behavior at school with poor self-adjustment, such as lazy to study, aloof, aggressive, truant and likes to oppose teachers. The purpose of this study is to determine whether there is an influence from a broken home family on student deviant behavior at SMP Negeri 2 Plered. The research was conducted using a quantitative approach with the research method used, namely causal quantitative. The data collection technique was carried out by distributing questionnaires (questionnaires) to 32 students as a sample with a total of 28 questionnaires that had been tested for validity and reliability on variables $(x)$ and $(y)$. The research results show that: first, the level of broken home families is said to be quite high at a percentage of $73 \%$. Second, the deviant behavior of students at SMP Negeri 2 Plered is quite high at a percentage of $72 \%$. Third, that there is a negative and significant effect between the broken home family variable $(x)$ on student deviant behavior (y) at SMP Negeri 2 Plered with a correlation value of -0.373 and the percentage of the relationship is $13.9 \%$ and $86.1 \%$ is influenced by the variable other.
\end{abstract}

Keywords: Broken Home, Student Deviant Behavior 


\begin{abstract}
Abstraksi
Dalam dunia pendidikan, sekolah bukan sepenuhnya menjadi penentu atas keberhasilan peserta didik, melainkan adanya partisipasi dan dorongan orang tua menjadi factor tercapainya tujuan pendidikan. Keberadaan Keluarga tentu menjadi point utama, keluarga harmonis akan membawakan suasana yang nyaman, aman damai dan tentram berbeda dengan keluarga yang kurang harmonis yang sering terjadi perselisishan, pertengkaran, perbedaan pendapat, sampai pada tindak kekerasan hal tersebut akan berpotensi buruk pada psikologi dan perkembangan anak. Dalam hal ini keluarga pecah (broken home) dapat dilihat dari dua aspek yaitu: (1) keluarga itu terpecah karena strukturnya tidak utuh sebab salah satu dari kepala keluarga itu meninggal dunia atau telah bercerai; (2) orang tua tidak bercerai akan tetapi struktur keluarga itu tidak utuh lagi karena ayah atau ibu sering tidak di rumah, dan tidak memperhatikan hubungan kasih sayang lagi. Dampak dari factor tersebut Anak yang berasal dari keluarga broken home akan rentan sekali melakukan perbuatan perilaku menyimpang di sekolah dengan penyesuian diri yang kurang baik, seperti malas belajar, menyendiri, agresif, membolos dan suka menentang guru. Adapun tujuan dalam penelitian ini adalah untuk mengetahui ada tidaknya pengaruh dari Keluarga broken home terhadap perilaku penyimpangan siswa di SMP Negeri 2 Plered. Penelitian dilakukan dengan menggunakan pendekatan kuantitatif dengan metode penelitian yang digunakan yaitu kuantitatif kausal. Teknik pengumpulan data dilakukan dengan cara menyebar angket (kuesioner) kepada 32 siswa sebagai sampel dengan jumlah angket sebanyak 28 butir soal yang telah di uji validitas dan reabilitas pada variable $(x)$ dan (y). Dari hasil penelitian menunjukan hasil bahwa: pertama, tingkat keluarga broken home dikatakan cukup tinggi pada prosentase 73\%. Kedua, perilaku penyimpangan siswa di SMP Negeri 2 Plered cukup tinggi pada prosentase 72\%. Ketiga, bahwasanya terdapat pengaruh negatif dan signifikan antara variable keluarga broken home $(x)$ terhadap perilaku penyimpangan siswa (y) di SMP Negeri 2 Plered dengan nilai korelasi -0,373 dan persentase hubungan sebesar $13,9 \%$ dan $86,1 \%$ di pengaruhi oleh variabel lain.
\end{abstract}

Kata Kunci : Keluarga Broken Home, Perilaku Penyimpangan Siswa

\title{
A. Pendahuluan
}

Pendidikan adalah suatu proses pembelajaran yang dilaksanakan untuk memperoleh pengetahuan baru yang di dapatkan melalui bimbingan, pelatihan dan pembinaan. Dalam UU SISDIKNAS No. 20 tahun 2003 Pendidikan adalah usaha sadar dan terencana untuk mewujudkan suasana belajar dan proses pembelajaran agar peserta didik secara aktif mengembangkan potensi dirinya untuk memiliki kekuatan spiritual keagamaan, pengendalian diri, kepribadian, kecerdasan, akhlak mulia, serta keterampilan yang di perlukan dirinya, masyarakat, bangsa, dan negara. ${ }^{1}$ Kebutuhan akan pendidikan merupakan hal yang tidak bisa di pungkiri, bahkan semua itu merupakan hak semua warga negara oleh karena itu Pendidikan merupakan tanggung jawab bersama antara keluarga, masyarakat dan pemerintah.

\footnotetext{
${ }^{1}$ Hasbullah, Dasar-Dasar Ilmu Pendidikan ( Jakarta: PT Raja Grafindo Persada, 2011), 4. 
Berkenaan dengan ini, didalam UUD'45 Pasal 31 Ayat (31) secara tegas disebutkan bahwa: " Tiap-tiap warga negara berhak mendapatkan pengajaran". 2 Sebagai lembaga pendidikan formal, sekolah berkewajiban memberikan pelayanan kepada masyarakat dalam mendidik warga Negara. Dan tidak hanya itu keluarga pun memiliki tanggung jawab dalam mensukseskan pendidikan. Tugas utama keluarga dalam pendidikan anak ialah sebagai peletak dasar bagi pendidikan akhlak dan pandangan hidup keagamaan. Sifat dan tabiat anak sebagian besar diambil dari kedua orang tuanya dan dari anggota keluarganya yang lain. ${ }^{3}$ Keberadaan orang tua utuh (lengkap) dengan orang tua tunggal (single parent) akan berbeda. Keberadaan Keluarga yang harmonis akan membawakan suasana yang nyaman, sebaliknya keluarga yang tidak harmonis akan berpotensi buruk bagi psikologi dan perkembangan anak. Anak yang berasal dari keluarga broken home sering di temui di sekolah dengan penyesuian diri yang kurang baik, seperti malas belajar, menyendiri, agresif, membolos dan suka menentang guru. ${ }^{4}$ Pernyataan diatas, juga telah di temukan oleh peneliti sebuah kasus permasalahan yang terjadi kepada peserta didik akibat dampak dari status keluarga broken home. Kasus tersebut ditemukan di SMP Negeri 2 Plered berdasarkan hasil wawancara dengan Ibu Yayah setiawati sebagai guru bidang study PAI sekaligus guru BP di SMP Negeri 2 Plered, beliau mengatakan bahwasanya terdapat kasus masalah yang sering terjadi di sekolah yaitu perihal perilaku penyimpangan siswa yang di sebabkan karena faktor keluarganya kurang harmonis ( broken home) . perilaku penyimpangan menurut Kartono dalam bukunya, Kenakalan remaja (juvenile delinquency) adalah perilaku negatif atau kenakalan anak-anak muda, merupakan gejala sakit (patologis) secara sosial pada anak-anak dan remaja yang disebabkan oleh satu bentuk pengabaian sosial, sehingga mereka mengembangkan bentuk perilaku yang menyimpang. ${ }^{5}$

Berdasarkan latar belakang masalah yang telah diuraikan di atas, dapat diidentifikasikan masalah perilaku penyimpangan siswa tersebut berasal dari keluarga broken home, kurangnya perhatian dari orang tua, dan kondisi perekonomian kelas menengah kebawah. Yang dirumuskan kedalam beberapa

\footnotetext{
${ }^{2}$ Ibid., 145

${ }^{3}$ Ibid., 89

${ }^{4}$ Sofyan S.Willis, Konseling Keluarga (Family Counseling), (Bandung:Alfabeta, 2017), 66.

${ }^{5}$ Kartini kartono, Patologi Sosial 2: Kenakalan Remaja ( Jakarta: PT RajaGrafindo Persada, 2013), 6.
} 
masalah yaitu : 1) Bagaimana Keluarga Broken Home di SMP Negeri 2 plered? 2) Bagaimana Bentuk-Bentuk Perilaku Penyimpangan yang di timbulkan oleh siswa di SMP Negeri 2 Plered? 3) Bagaimana pengaruh dari Keluarga Broken Home terhadap Perilaku Penyimpangan Siswa di SMP Negeri 2 Plered? Yang bertujuan, 1) Untuk mengetahui Keluarga Broken Home di SMP Negeri 2 Plered 2) Untuk mengetahui Bentuk Perilaku Menyimpang yang terjadi oleh siswa di SMP Negeri 2 Plered 3) Untuk mengetahui Pengaruh keluarga broken home terhadap perilaku penyimpangan siswa di SMP Negeri 2 Plered. Dengan harapan hal ini dapat memberikan manfaat bagi semua pihak yang terkait di dalam maupun di luar lingkungan sekolah.

\section{B. Teori / Konsep}

1. Definisi Keluarga

Keluarga merupakan arena utama dan pertama untuk melakukan interaksi sosial dan mengenal perilaku-perilaku yang dilakukan oleh orang lain. Karena itu keluraga merupakan wadah yang memiliki arti penting dalam pembentukan karakter, hubungan kekerabatan, sosial dan kreativitas para anggotanya. ${ }^{6}$

Menurut M.I Soelaeman ( 1978 : 4-5) mengemukakan pendapat para ahli mengenai pengertian keluarga, yaitu:

1) F.J. Brown berpendapat bahwa di tinjau dari sudut panjang sosiologis, keluarga dapat diartikan dua macam, yaitu a) dalam arti luas, keluarga meliputi semua pihak yang ada hubungan darah atau keturunan yang dapat dibandingkan dalam" Clan" atau marga; b) dalam arti sempit keluarga meliputi orang tua dan anak. ${ }^{7}$

2) Machiver menyebutkan lima ciri khas keluarga yang umum terdapat dimanamana, yaitu a) hubungan berpasangan kedua jenis, b) perkawinan atau bentuk ikatan lain yang mengokohkan hubungan tersebut, c) pengakuan akan keturunan, d) kehidupan ekonomis yang diselenggarakan dan di nikmati bersama, dan, e) kehidupan berumah tangga. ${ }^{8}$

\section{Definisi Broken Home}

Broken berarti "Kehancuran", sedangkan Home berarti "Rumah". Broken Home memiliki arti adanya kehancuran di dalam rumah tangga yang disebabkan

\footnotetext{
${ }^{6}$ Ulfiah, psikologi keluarga ( Bogor: Ghalia Indonesia, 2016), 1.

${ }^{7}$ M.I. Soelaeman, pendidikan dalam keluarga (Bandung : Bhumi siliwangi, 1978), 4.

${ }^{8}$ Ibid., 5

76 | Paedagogie: P-ISSN: 2337-6848, E-ISSN : 2723-5971
} 
kedua suami istri mengalami perbedaan pendapat. Broken Home disini memiliki banyak arti yang bisa di karenakan adanya perselisihan atau percekcokan antara suami istri, akan tetapi tetap tinggal satu rumah. Bisa juga broken home diartikan kehancuran Rumah Tangga sampai terjadi perceraian kedua orang tua. ${ }^{9}$ Menurut Chaplin (2002 : 71) keluarga broken home ( keluarga retak, rumah tangga berantakan) adalah keluarga atau rumah tangga tanpa hadirnya salah seorang dari kedua orang tua (ayah, atau ibu), disebabkan oleh meninggal, perceraian, meninggalkan keluarga, dan lain-lain. ${ }^{10}$ Menurut Sofyan S. Willis dalam bukunya Keluarga pecah (broken home) dapat dilihat dari dua aspek yaitu:

1. keluarga itu terpecah karena strukturnya tidak utuh sebab salah satu dari kepala keluarga itu meninggal dunia atau telah bercerai;

2. orang tua tidak bercerai akan tetapi struktur keluarga itu tidak utuh lagi karena ayah atau ibu sering tidak di rumah, dan atau tidak memperhatikan hubungan kasih sayang lagi. Misalnya orang tua sering bertengkar sehingga keluarga itu tidak sehat secara psikologi. ${ }^{11}$

Berdasarkan dari pernyataan definisi tentang keluarga dan broken home, penulis dapat menyimpulkan bahwa keluarga merupakan unit sosial terkecil yang berjumlah dua orang atau lebih yang terdiri atas kepala keluarga ayah, ibu, dan anakanak serta anggota-anggota keluarga lainnya yang berasal dari pertalian darah. Sedangkan broken home adalah suatu keretakan dalam rumah tangga antara suami dan istri yang dalam setiap harinya sering terjadi perselisihan, percekcokkan, perbedaan pendapat, kesibukan orang tua dan kurang harmonis. Sehingga dapat penulis simpulkan keluarga broken home adalah unit keluarga social terkecil yang di dalamya terjadi keretakan. Adapun yang menjadi topic inti dalam pembahasan teori ini yaitu tentang keluarga keluarga broken home.

\section{Faktor-faktor yang Mempengaruhi Keluarga Broken Home}

Beberapa faktor yang menjadi penyebab terjadinya keluarga broken home yaitu sebagai berikut:

\footnotetext{
${ }^{9}$ Vendi prasetyo, Pengertian Broken Home, http://sobatbaru.blogspot.com/2008/04/pengertian-brokenhome.html. Diakses pada7 Maret 2020

${ }^{10}$ Ummi Hanik, Peran Guru Bimbingan Konseling dalam Mengatasi Kenakalan Siswa Korban Broken Home di SMK MA'ARIF NU 1 Wonolopo Kecamatan Mijen Kota Semarang, Skripsi (Semarang : Universitas Islam Negeri Walisongo, 2018), 40

${ }^{11}$ Sofyan S.Willis, Konseling Keluarga (Family Counseling), 66.
} 
a. Kurang atau putus komunikasi diantara anggota keluarga terutama ayah dan ibu

b. Sikap Egosentrisme

c. Masalah ekonomi

d. Masalah kesibukan

e. Masalah pendidikan

f. Masalah perselingkuhan

g. Jauh dari agama

Dari beberapa faktor yang timbul dalam keluarga broken home, maka hal tersebut sangat berpengaruh sekali terhadap interaksi yang berlangsung dalam kesehariannya. Apabila dalam suatu keluarga terjadi suatu perceraian atau keretakan didalamnya, maka sedikit banyak akan mempengaruhi perubahan perhatian dari orang tua terhadap anaknya baik perhatian fisik, seperti sandang, pangan, dan pendidikan maupun perhatian psikis seperti, kasih sayang dan intensitas interaksi.

\section{Dampak Keluarga Broken Home pada Anak}

Menurut Dadang Hawari (1997: 163-165) anak yang di besarkan dalam keluarga yang mengalami disfungsi mempunyai resiko yang lebih besar untuk bergantung tumbuh kembang jiwanya (misalnya berkeribadian antisosial), dari pada anak yang dibesarkan dalam keluarga yang harmonis dan tuh ( sakinah). ${ }^{12}$

Menurut Sofyan S. Willis dalam bukunya mengemukakan bahwa dampak yang terjadi akibat dari keluarga Broken home bahwasanya, Anak yang berasal dari keluarga broken home sering di temui di sekolah dengan penyesuian diri yang kurang baik, seperti malas belajar, menyendiri, agresif, membolos dan suka menentang guru. ${ }^{13}$ Selain itu dampak dari keluarga broken home, mereka sering mengalami depresi mental. Anak korban broken home jiwanya tidak stabil karena terbebani masalah, jiwaya suka berontak, suka melawan, suka menentang, dan disekolah anak tersebut banyak melanggar aturan sekolah, sering bolos pada jamjam belajar sering alpa, dan hari-hari di kelas tidak bisa tenang dan suka berpindahpindah tempat dan suka jalan-jalan. ${ }^{14}$

\footnotetext{
${ }^{12}$ Syamsu Yusuf, Psikologi Perkembangan Anak dan Remaja ( Bandung: PT Remaja Rosdakarya, 2011), 43.

${ }^{13}$ Sofyan S Willis, Konseling keluarga, 66

${ }^{14}$ Mukhlis Aziz, "Perilaku Sosial Anak Remaja Korban Broken Home dalam berbagai Perspektif" : Jurnal Al Ijtimaiyyah, vol. 1, No. 1, (Januari - Juni 2015), 47
} 


\section{Indikator Keluarga Broken Home}

Menurut Syamsu Yusuf (2011:44) dalam bukunya dikatakan keretakan dalam dalam keluarga (broken home) tentunya memiliki kriteria ciri-ciri sebagai berikut:

a. Kematian salah satu atau kedua orang tua

b. Divorce, (kedua orang tua berpisah atau bercerai)

c. Poor marriage, (hubungan kedua orang tua tidak baik)

d. Poor parent-child relationship, (hubungan orang tua dengan anak tidak baik)

e. High tension and low warmth, (suasana rumah tangga yang tegang dan tanpa kehangatan)

f. parent's absence (orang tua sibuk dan jarang ada di rumah)

g. Personality psychological disorder, (salah satu atau kedua orang tua mempunyai kelainan kepribadian atau gangguan kejiwaan). ${ }^{15}$

\section{Definisi Perilaku Penyimpangan}

Menurut Paul B. Horton Penyimpangan adalah setiap perilaku yang tidak berhasil menyesuaikan diri dengan kehendak-kehendak masyarkat atau kelompok tertentu dalam masyarakat. Menurut Bruce J. Cohen perilaku menyimpang adalah setiap perilaku yang tidak berhasil menyesuaikan diri dengan kehendak-kehendak masyarakat atau kelompok tertentu dalam masyarakat. Begitupun sesuai dengan pendapat Kartono dalam bukunya, kenakalan remaja (juvenile delinquency) adalah perilaku negatif atau kenakalan anak-anak muda, merupakan gejala sakit (patologis) secara sosial pada anak-anak dan remaja yang disebabkan oleh satu bentuk pengabaian sosial, sehingga mereka mengembangkan bentuk perilaku yang menyimpang. ${ }^{16}$

Menurut ajaran islam perbuatan salah atau menyimpang ialah perbuatan atau perilaku yang bertentangan dengan aturan-aturan pedoman agama islam yaitu: AlQur'an dan As-sunah. Nabi Muhammmad Saw, selaku rasulullah dijadikan teladan yang baik sebab dalam dirinya terdapat sifat-sifat yang wajib kita contoh dan kita teladani. Hal ini difirmankan dalam Al Qur'an Surat Al Ahzab ayat 21

\footnotetext{
${ }^{15}$ Syamsu Yusuf, Psikologi Perkembanga Anak dan Remaja , 44.

${ }^{16}$ Kartini kartono, Patologi Sosial 2: Kenakalan Remaja, 6.
} 


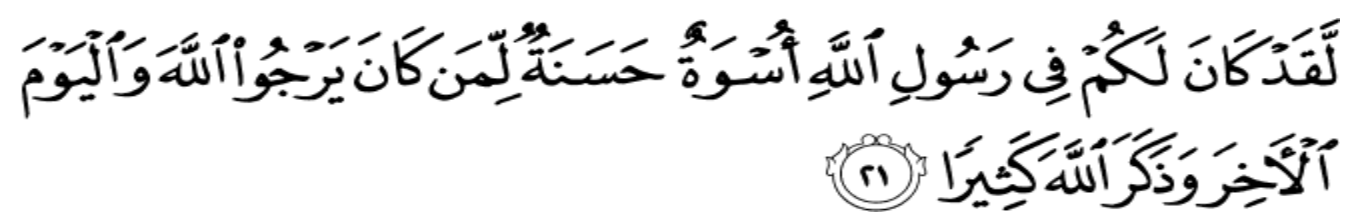

artinya "sesungguhnya telah ada pada diri rasulullah saw itu ada suri tauladan yang baik bagimu (yaitu) bagi orang yang mengharap (rahmat) Allah dan (kedatangan) hari kiamat dan dia banyak enyebut Allah" (Qs. Al-Ahzab : 21).

Pada kasusnya Perilaku penyimpangan yang dibahas dalam penelitian ini yaitu penyimpangan perilaku yang di lakukan oleh siswa yang telah melanggar aturan-aturan yang disudah di tetapkan di sekolah. Penyimpangan perilaku ini apabila tidak cepat untuk di tanggapi di khawatirkan akan banyak sekali remajaremaja kita yang rusak akhlak dan moral nya. Sebagaimana kita ketahui bahwasanya remaja adalah generasi penerus bangsa. Apabila banyak remaja yang berperilaku menyimpang akan menjadi masalah besar bagi bangsa kita, karena nasib bangsa kita di masa yang akan datang terletak di tangan generasi muda. Apabila generasi mudanya mengalami kebobrokan moral, maka bangsa ini akan mengalami kemunduran. Kenakalan remaja atau penyimpangan perilaku pada umumnya terjadi pada usia sekolah SMP dan SMA. Karena pada usia sekolah tersebut remaja rentan dipengaruhi dan jiwa remajanya masih sangat labil.

Menurut Monks dkk, (2004) Apabila dilihat berdasarkan rentang usianya, masa remaja secara global berlangsung pada usia 12 sampai 21 tahun, dengan pembagian 12 sampai 15 tahun adalah masa remaja awal, 15 sampai 18 tahun adalah masa remaja pertengahan, dan 18 sampai 21 tahun adalah masa remaja akhir. ${ }^{17}$

\section{Bentuk-bentuk Perilaku Menyimpang Siswa}

Adapun Bentuk-bentuk perilaku menyimpang menurut para ahli : Menurut Adler ( 1952) yang di tulis oleh Kartini Kartono adalah sebagai berikut :

1. Kebut-kebutan di jalanan yang mengganggu keamanan, dan membahayakan jiwa sendiri dan orang lain.

2. Perilaku ugal-ugalan, berandalan, ukuran yang mengacaukan ketentraman masyarakat sekitar. Tingkah laku ini bersumber pada

\footnotetext{
${ }^{17}$ Lidya Sayidatun Nisya, "Religiusitas, Kecerdasan Emosional dan Kenakalan Remaja," : Jurnal Psikologi Volume 7 No. 2, (Agustus 2012), $562-58$.
} 
kelebihan energi dan dorongan primitif yang tidak terkendali serta kesukaan meneror lingkungan.

3. Perkelahian antar geng, antar kelompok, antar sekolah, antar suku, sehingga kadang-kadang membawa korban jiwa

4. Membolos sekolah lalu bergelandangan sepanjang jalan, atau bersembunyi di tempat-tempat terpencil sambil melakukan bermacammacam kedurjanaan dan tindak asusila.

5. Kriminalitas anak siswa dan adolesons antara lain berupa perbuatan mengancam, mengintimidasi, memeras, maling, mencopet, merampas, menjambret, menyerang, membunuh, menyiksa dan pelanggaran yang lainya.

6. Berpesta pora sambil mabuk-mabukan, melakukan hubungan seks bebas, dan berbagai tindakan yang mengganggu ketentraman dan ketenangan lingkungan ${ }^{18}$

Adapun bentuk bentuk penyimpangan yang sering terjadi disekolah SMP Negeri 2 Plered seperti membolos, datang terlambat, tidak pernah memperhatian guru, tidak mengerjakan tugas, kepada guru tidak sopan, suka melawan, dikelas selalu bikin rusuh, suka mengganggu teman, caper, suka jalan-jalan di kelas atau sebentar-bentar minta izin keluar ke kamar kecil, suka berkelahi, suka memanjat tembok sekolah, meminta uang pada teman secara paksa. Sehingga karena perilakuperilaku mereka tersebut membuat guru dan murid lainnya merasa tidak nyaman, bahkan sangat mengganggu ketenangan semua pihak.

\section{Sebab-sebab Perilaku Menyimpang Siswa}

Menurut Bimo Walgito ada tiga penyebab perilaku menyimpang atau kenakalan pada remaja yaitu:

1. Keadaan keluarga

a. Keluarga yang broken home ( keluarga pecah)

b. Kematian salah satu dari orang tua

c. Ketidak hadiran orang tua dalam waktu yang lama secara kontinyu

2. Keadaan sekolah

\footnotetext{
${ }^{18}$ Kartini kartono, Patologi Sosial 2: Kenakalan Remaja,21-23.
} 
a. Karena kesulitan dalam bidang ekonomi, guru tidak dapat memberikan perhatian terhadap anak didiknya, sehingga keadaan ini akan membawa pengaruh sikap guru pada anak.

b. Guru sering tidak masuk belajar, akibatnya anak didik terlantar dan tidak mendapat contoh secara langsung dari gurunya.

c. Gedung dan peralatan yang tidak memenuhi syarat walaupun secara minimal, sehingga mudah menimbulkan frustasi.

d. Jumlah sekolah yang belum mencukupi dapat menimbulkan persoalan tersendiri. Tidak adanya norma yang satu diantara para guru, membuat anak didik mengalami kebingungan terhadap aturan ketepatan yang harus dianut.

3. Keadaan masyarakat

Masyarakat merupakan tempat pendidikan yang ketiga setelah keluarga dan sekolah, secara langsung memberikan pengaruh terhadap kehidupan anak. Adapun pengaruh yang dapat menimbulkan perilaku menyimpang atau kenakalan remaja adalah:

a) Keadaan sosial pada umumnya

b) Fasilitas rekreasi yang kurang memadai

c) Kegoyahan norma dalam masyarakat, menjadikan remaja bingung dan kehilangan panutan

d) Adanya pengaruh dari norma-nnorma dari luar

e) Media masa, yang memberikan pengaruh informasi yang negatif

f) Kurang atau tidakya pimpinan yang dapat menjadikan tempat

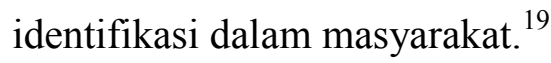

\section{Indikator Perilaku Menyimpang Siswa}

Dalam hal ini peneliti menggunakan teori asosiasi diferensial dari Edwin $\mathrm{H}$ Sutherland. Menurut Sutherland preferensi ke perilaku menyimpang itu "ditransmisikan secara kultural" sama dengan menyatakan bahwa perilaku menyimpang itu dipelajari melalui interaksi sosial. Teori ini menjelaskan mengapa orang tertentu masuk ke dalam dunia kejahatan. Ketika kelompok diorganisasikan untuk kejahatan, pandangan yang mendukung pelanggaran hukum akan menguat.

\footnotetext{
${ }^{19}$ Bimo Walgito, Kenakalan Remaja ( Yogyakarta:UGM Press, 1982), 10.
} 
Oleh karena itu, makin banyak orang yang mungkin belajar berasosiasi secara diferensial dengan- nilai-nilai menyimpang.

Sutherland mengemukakan dalam beberapa proposisi bahwa perilaku menyimpang itu merupakan:

1. Perilaku menyimpang dipelajari oleh seseorang dalam interaksinya dengan orang-orang lain dan melibatkan proses komunikasi. Secara teoritis sekurang-kurangnya ada dua syarat bagi interaksi sosial.Yaitu terjadinya kontak sosial dan komunikasi.

2. yang menjadi bagian utama dari perilaku menyimpang terjadi di dalam kelompok-kelompok personal yaitu terjalin hubungan yang intim atau akrab.

3. Rasa solidaritas

4. melanggar norma lebih menguntungkan dari pada tidak melanggar.

Menurut Hirschi (1969). Sebagai ahli teori kontrol menilai perilaku menyimpang adalah konsekuensi logis dari kegagalan seseorang untuk mentaati hukum. Ia mengajukan beberapa proposisi diantaranya:

1. berbagai bentuk pengingkaran terhadap aturan-aturan sosial adalah akibat dari kegagalan mensosialisasi individu untuk bertindak konform terhadap aturan atau tata tertib yang ada.

2. kontrol internal lebih berpengaruh dari pada kontrol eksternal. Dalam hal ini adanya suatu dorongan, individu melakukan tindakan menyimpang. ${ }^{20}$

Berdasarkan pemaparan pendapat pada para ahli diatas dapat peneliti simpulkan bahwa indikator dalam perilaku penyimpangan siswa itu diataranya:

1. Interaksi Sosial

2. Terjalinnya hubungan yang intim dan akrab

3. Rasa solidaritas

4. Melanggar norma lebih menguntungkan dari pada tidak melanggar

5. Kegagalan mensosialisasi individu untuk bertindak konform terhadap aturan atau tata tertib yang ada

6. Motivasi internal

\section{Metode Penelitian}

\footnotetext{
${ }^{20}$ Risjad Primadha, Perilaku Menyimpang Siswa SMP

file://C:/Users/ASUS/Downloads/toeri\%20keluarga $\% 20$ broken $\% 20 \mathrm{dan} \% 20$ perilkau $\% 20$ penyimpngan/in dikator\%20penyimpangan.pdf, Diakses pada 15 april 2020
} 


\section{Pendekatan dan Metode Penelitian}

Pendekatan dalam penelitian ini menggunakan pendekatan kuantitatif. Penelitian kuantitatif merupakan metode penelitian yang berlandaskan pada filsafat positivisme, digunakan untuk meneliti pada populasi atau sample tertentu, Teknik pengambilan sample pada umumnya dilakukan secara random, pengumpulan data menggunakan instrument penelitian, analisis data bersifat kuantitatif/statistic dengan tujuan untuk menguji hipotesis yang telah ditetapkan. ${ }^{21}$ Pendekatan tersebut dipilih dengan alasan untuk mendapatkan fakta tentang pengaruh keluarga broken home terhadap perilaku penyimpangan siswa.

Adapun metode penelitian yang digunakan yaitu kuantitatif kausal. Variable bebas (X) dalam penelitian ini adalah Keluarga Broken Home sedangkan variable terikat (Y) pada penelitian ini adalah perilaku Penyimpangan Siswa. Agar lebih jelasnya dapat dilihat pada konstelasi penelitian sebagai berikut :

\section{Populasi dan Sampel}

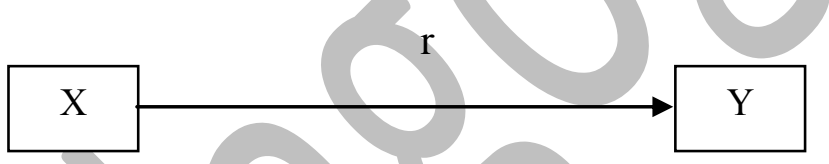

a. Populasi

Populasi adalah wilayah generalisasi yang terdiri atas obyek/subjek yang mempunyai kualitas dan karaktristik tertentu yang ditetapkan oleh peneliti untuk dipelajari dan kemudian ditrik kesimpulannya. ${ }^{22}$

Adapun jumlah populasi penelitian, secara umum diambil dari seluruh siswasiswi kelas VIII SMP Negeri 2 Plered dengan jumlah keseluruhan terdiri 146 siswa-siswi.

b. Sampel

Sampel adalah bagian dari jumlah dan karakteristik yang dimiliki oleh populasi tersebut. Bila populasi besar, dan peneliti tidak mungkin mempelajari semua yang ada pada populasi, dikarenakan keterbatasan

${ }^{21}$ Ibid., 14.

${ }^{22}$ Ibid., 80 
dana dan tenaga dan waktu, maka peneliti dapat menggunakan sampel yang diambil dari pupolasi itu. ${ }^{23}$

Berdasarkan pendapat Suharsimi Arikunto yang menyebutkan bahwa " apabila subjek kurang dari 100 alangkah lebih baik bila sampelnya diambil semua sehingga penelitiannya merupakan penelitian populasi. Sebaliknya jika jumlah subjek lebih besar, maka dapat diambil antara $10-15 \%$ atau $20-25 \%$ atau lebih.

Berdasarkan pernyataan di atas, pengambilan sampel pada penelitian tersebut diambil sebanyak $22 \%$ dengan hasil perhitungan $22 / 100=$ $0,22 \times 146=32,12$. jadi dari $22 \%$ dari jumlah populasi, yang di ambil sampel sebanyak 32 siswa. Data tersebut di sesuaikan berdasarkan hasil observasi dengan guru BP dan dari data buku induk siswa.

\section{Teknik pengumpulan data}

Metode atau teknik pengumpulan data yang digunakan adalah field research (penelitian lapangan) yakni penelitian yang dilakukan dilapangan untuk mengumpulkan data-data yang berhubungan dengan permasalahan yang ada dalam penelitian. Dalam memperoleh data penelitian ini peneliti menggunakan metode pokok yaitu:

\section{a. Kuesioner (Angket)}

Kuesioner merupakan teknik pegumpulan data yang dilakukan dengan cara memberi seperangkat pertanyaan atau pernyataan tertulis kepada responden untuk dijawabnya. Kuesioner merupakan teknik pengumpulan data yang efesien bila peneliti tahu dengan hasil variabel yang akan diukur dan tahu apa yang diharapkan responden. 24

b. Metode Observasi

Observasi sebagai teknik pengumpulan data mempunyai ciri yang spesifik bila dibandingkan dengan teknik yang lain, yaitu wawancara dan kuesioner. Kalau wawancara dan kuesioner selalu berkomunikasi

${ }^{23}$ Ibid., 81

${ }^{24}$ Ibid., 142 
dengan orang, maka observasi tidak terbatas pada orang, tetapi juga obyek-obyek alam lain. ${ }^{25}$

\section{Instrument penelitian}

Instrumen penelitian adalah suatu alat yang digunakan untuk mengukur fenomena alam maupun social yang diamati. ${ }^{26}$ Instrument penelitian digunakan untuk mengukur variable yang diteliti. ${ }^{27}$

a) angket, dengan cara menyusun pertanyaan dan kuesioner

Pada setiap pertanyaan dalam instrument disediakan lima pilihan jawaban pertanyaan positif dengan sekor masing-masing sebagai berikut

$\begin{array}{ll}\mathrm{SS}(\text { Sangat Setuju }) & =5 \\ \mathrm{~S}(\text { Setuju }) & =4 \\ \mathrm{R}(\text { Ragu-ragu }) & =2 \\ \text { TS ( Tidak Setuju) } & \\ \text { STS (Sangat Tidak Setuju) } & =1\end{array}$

Dan untuk pilihan jawaban pertanyaan negative diberi skor masingmasing sebagai berikut:
SS ( Sangat Setuju)
$=1$
S (Setuju)
$=2$
R ( Ragu-ragu)
$=3$
TS ( Tidak Setuju)
$=4$
STS (Sangat Tidak Setuju)
$=5$
b) kisi kisi dan instrument

\section{1) Uji instrument}

${ }^{25}$ Ibid., 145

${ }^{26}$ Sugiyono, Metode Penelitian, 305.

${ }^{27}$ Ibid., 133

86 | Paedagogie: P-ISSN: 2337-6848, E-ISSN : 2723-5971 


\section{a. Uji validasi}

Validitas adalah suatu ukuran yang menunjukan tingkat-tingkat kevalidan atau kesahihan sesuatu instrument. ${ }^{28}$ Sebuah instrumen dikatakan valid apabila mampu mengukur apa yang diinginkan dan sebuah instrumen dikatakan valid apabila dapat mengungkap data dari variabel yang diteliti secara tepat. Sugiyono, pengujian validitas tiap butir digunakan analisis item dengan teknik korelasi, yaitu mengkorelasikan skor tiap butir dengan skor total yang merupakan jumlah tiap skor butir. Uji validitas digunakan untuk mengetahui kelayakan butir-butir dalam suatu daftar pertanyaan dalam mendefinisikan suatu variable. Uji validitas sebaiknya dilakukan pada setiap butir pertanyaan di uji validitas. Hasil $r$ hitung kita bandingkan dengan $r$ tabel dimana $d f=n-2$ dengan $\operatorname{sig} 5 \%$.

Jika $\mathrm{r}$ tabel $<\mathrm{r}$ hitung maka valid. Dalam penelitian ini $\mathrm{r}$ tabel diperoleh dari nilai signifikan yang sebesar 0,05 atau sig $5 \%$ dan $n=40$, sehingga nilai $r$ tabel adalah $0,349 .^{29}$

$$
r_{x y}=\frac{N \sum x y-\left(\sum x\right)\left(\sum y\right)}{\sqrt{\left(N \sum x^{2}\right)-\left(\sum x\right)^{2}\left(N \sum y^{2}\right)-(N y)^{2}}}
$$

r : Koefisien korelasi

N : Jumlah Subjek

$\sum \mathrm{x} \quad$ : Jumlah skor item

$\sum \mathrm{y}$ : Jumlah skor total

$\sum x^{2} \quad$ : Jumlah kuadrat skor item

$\sum y^{2} \quad$ : Jumlah kuadrat skor total

\section{b. Uji Reabilitas}

Suatu instrumen dapat cukup dapat dipercaya untuk digunakan sebagai pengumpul data jika instrument tersebut sudah baik. Instrumen yang sudah baik dan dapat dipercaya akan dapat menghasilkan data yang dapat dipercaya juga. ${ }^{30}$

${ }^{28}$ Suharsimi Arikunto. Prosedur Penelitian. (Jakarta: PT. Rineka Cipta, 2010) , 211.

${ }^{29}$ Sugiyono. Metodologi Penelitian Pendidikan: Pendekatan kuantitatif, kualitatif, dan R\&D. (Bandung: Alfabeta, 2006), 187.

${ }^{30}$ Suharsimi Arikunto. Prosedur Penelitian (Jakarta: PT. Rineka Cipta, 2010), 221. 
Meskipun datanya memang benar sesuai dengan kenyataannya, maka berapa kalipun diambil tetap sama. Uji reliabilitas dapat dilakukan secara bersama-sama terhadap seluruh butir pertanyaan. Jika nilai Alpha $>0,60$ maka reliable. Pengujian yang digunakan untuk penelitian ini adalah dengan teknik Cronbach's Alpha. Rumus yang dipakai untuk mengetahui koefisien Cronbach's Alpha, yaitu : ${ }^{31}$

$$
\begin{array}{ll}
\boldsymbol{r} \mathbf{1 1}=\left[\frac{\boldsymbol{k}}{(\boldsymbol{k}-\mathbf{1})}\right]\left[\mathbf{1}-\frac{\sum \boldsymbol{\sigma} \boldsymbol{b}^{\mathbf{2}}}{\boldsymbol{\sigma} \mathbf{1}^{\mathbf{2}}}\right] \\
\text { r } 11 \quad \text { : Reliabilitas } \\
\mathrm{k} \quad \text { : banyalnya butir pertanyaan } \\
\sum \sigma b^{2} & \text { : jumlah varian butir } \\
\sigma^{2} 1^{2} & \text { : Varians total }
\end{array}
$$

\section{Hasil Penelitian dan Pembahasan}

\section{Hasil Penelitian}

a. Deksripsi variable $x$

\section{1) Prosentase}

Membuat distribusi frekuensi, distribusi frekuensi merupakan urutan tiap-tiap skor, satuan-satuan unit dalam suatu data tertentu. Data yang berasal dari sumber data perlu disusun dalam bentuk table distribusi frekuensi agar lebih praktis dan mudah dibaca. Prosentase mendeskripsikan perolehan skor secara skala prosentase berdasarkan:

o Nilai komulatif adalah nilai dari setiap item pernyataan yang merupakan jawaban dari 32 sampel.

- Persentase adalah nilai komulatif item dibagi dengan nilai frekuensinya dikalikan $100 \%$.

○ Jumlah sampel variabel X dan Y sebanyak 32 orang dari nilai skala pengukuran terbesar adalah 5 sedangkan skala pengukuran terkecil 1 . Maka nilai komulatif terbesar adalah 32 X $5=160$ dan jumlah nilai komulatif terkecil adalah $32 \times 1=32$. Adapun nilai persentase

${ }^{31}$ Ibid., 223 
terbesar adalah $(160 / 160) \times 100 \%=100 \%$ dan nilai persentase terkecil adalah $(32 / 160) \times 100 \%=20 \%$. Dari persentase tertinggi dan terendah tersebut dapat diperoleh nilai rentang $100 \%-20 \%=$ $80 \%$. Dan nilai rentang tersebut dibagi dengan lima skala pengukuran (80\% / 5), maka dapat ditetapkan klasifikasi kriteria penilaian sebagai berikut:

\section{TABEL 4.11}

PRESENTASE DAN KRITERIA PENILAIAN

\begin{tabular}{|l|c|c|}
\hline NO & PRESENTASE & KRITERIA \\
\hline 1 & $85-100$ & Sangat baik \\
\hline 2 & $69-84$ & Baik \\
\hline 3 & $53-68$ & Cukup \\
\hline 4 & $37-52$ & Kurang \\
\hline 5 & $20-36$ & Kurang sekali \\
\hline
\end{tabular}

Dengan keterangan sebagai berikut:

- Jumlah soal angket $\quad$ : 28

- Jumlah sample : :32

- Total perolehan skor $\quad$ : 3288

- Prosentase : $73 \%$

- Rata-rata : $73 \%$

- Kategori perolehan skor : baik

2) Ukuran Pemusatan (Modus, Mean, Median)

TABEL 4.12

ANALISIS DESKRITIF VARIABEL $X$

\section{Statistics}

Skor

\begin{tabular}{|ll|r|}
\hline $\mathrm{N}$ & Valid & 32 \\
& Missing & 0 \\
Mean & & 73,38 \\
\hline
\end{tabular}

Paedagogie: P-ISSN: 2337-6848, E-ISSN : 2723-5971 | 89 


$\mid$\begin{tabular}{l|r} 
Median & 74,00 \\
Mode & 74 \\
Std. Deviation & 5,339 \\
Variance & 28,500 \\
Range & 23 \\
Minimum & 61 \\
Maximum & 84 \\
Sum & 2348 \\
\hline
\end{tabular}

Berdasarkan hasil analisis data, diperoleh nilai tendensi sentral variabel keluarga broken home. Hasil analisis menunjukan nilai :
1. Maksimum : 84
2. Minimum : 61
3. Mean : 73,38
4. Modus : $: 74$
5. Median $: 74,00$

3) Ukuran Penyebaran ( Range, Varians, Standar Deviasi)

Hasil data mengenai penyebaran data dari variabel keluarga broken home, yang di ambil dari 32 responden menunjukan bahwa :
1. Range
$: 23$
2. Varians $: 28,500$
3. Standar Deviasi : 5,339

\section{4) Display Data ( Tabel Histogram)}

Penyebaran skor dari variabel Keluarga Broken Home secara deskriptif dalam histogram pada gambar berikut

GAMBAR 4.1

HISTOGRAM DESKRIPTIF VARIABEL $X$ 


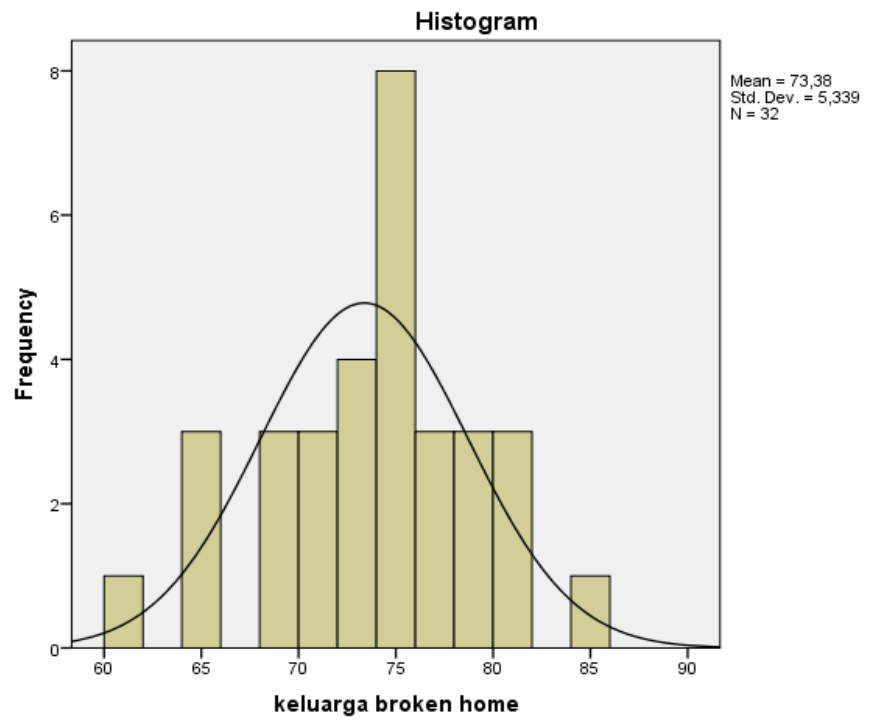

Berdasarkan gambar diatas, menunjukan histogram memiliki bentuk normal, rata-rata histogram terletak ditengah range data. Frekeunsi data paling tinggi di tengah dan menurun secara bertahap dan simetris pada kedua sisina, maka hal tersebut menunjukan bahwa keluarga broken home berdistribusi normal.

\section{a) Deskripsi Variabel Y}

\section{1) Prosentase}

Prosentase mendeskripsikan perolehan skor secara skala prosentase berdasarkan:

Nilai komulatif adalah nilai dari setiap item pernyataan yang merupakan jawaban dari 32 sampel.

- Persentase adalah nilai komulatif item dibagi dengan nilai frekuensinya dikalikan 100\%.

○ Jumlah sampel variabel X dan Y sebanyak 32 orang dari nilai skala pengukuran terbesar adalah 5 sedangkan skala pengukuran terkecil 1. Maka nilai komulatif terbesar adalah 32 X $5=160$ dan jumlah nilai komulatif terkecil adalah $32 \times 1=32$. Adapun nilai persentase terbesar adalah $(160 / 160) \times 100 \%=100 \%$ dan nilai persentase terkecil adalah $(32 / 160) \times 100 \%=20 \%$. Dari persentase tertinggi dan terendah tersebut dapat diperoleh nilai rentang $100 \%-20 \%=80$ 
\%. Dan nilai rentang tersebut dibagi dengan lima skala pengukuran (80\% / 5), maka dapat ditetapkan klasifikasi kriteria penilaian sebagai berikut:

TABEL 4.13

PRESENTASE DAN KRITERIA PENILAIAN

\begin{tabular}{|l|c|c|}
\hline NO & PRESENTASE & KRITERIA \\
\hline 1 & $85-100 \%$ & Sangat Baik \\
\hline 2 & $69-84 \%$ & Baik \\
\hline 3 & $53-68 \%$ & Cukup \\
\hline 4 & $37-52 \%$ & Kurang \\
\hline 5 & $20-36 \%$ & Kurang sekali \\
\hline
\end{tabular}

Dengan keterangan sebagai berikut:

- Jumlah soal angket $: 28$

- Jumlah sample $: 32$

- Total perolehan skor $: 3230$

- Prosentase $: 72 \%$

- Rata-rata $: 72 \%$

- Kategori perolehan skor : Baik

2) Ukuran Pemusatan (Modus, Mean, Median)

TABEL 4.14

ANALISIS DESKRITIF VARIABEL Y

Statistics

Skor

\begin{tabular}{|l|r|}
\hline N $\quad$ Valid & 32 \\
& Missing \\
Mean & 0 \\
Std. Error of Mean & 67,94 \\
Median & 1,712 \\
Mode & 68,00 \\
Std. Deviation & 64 \\
\end{tabular}




\begin{tabular}{|l|r|} 
Variance & 93,738 \\
Range & 53 \\
Minimum & 29 \\
Maximum & 82 \\
Sum & 2174 \\
\hline
\end{tabular}

Berdasarkan hasil analisis data, diperoleh nilai tendensi sentral variabel perilaku penyimpangan siswa. Hasil analisis menunjukan nilai :
1. Maksimum : 82
2. Minimum : 29
3. Mean : 67,94
4. Modus : 64
5. Median : 68,00

3) Ukuran Penyebaran ( Range, Varians, Standar Deviasi)

Hasil data mengenai penyebaran data dari variabel Perilaku Penyimpangan Siswa yang di ambil dari 32 responden menunjukan bahwa

1. Range $: 29$

2. Varians : 93,738

3. Standar Deviasi $: 9,68$

4) Display Data ( Tabel Histogram)

GAMBAR 4.2

HISTOGRAM DESKRIPTIF VARIABEL Y 


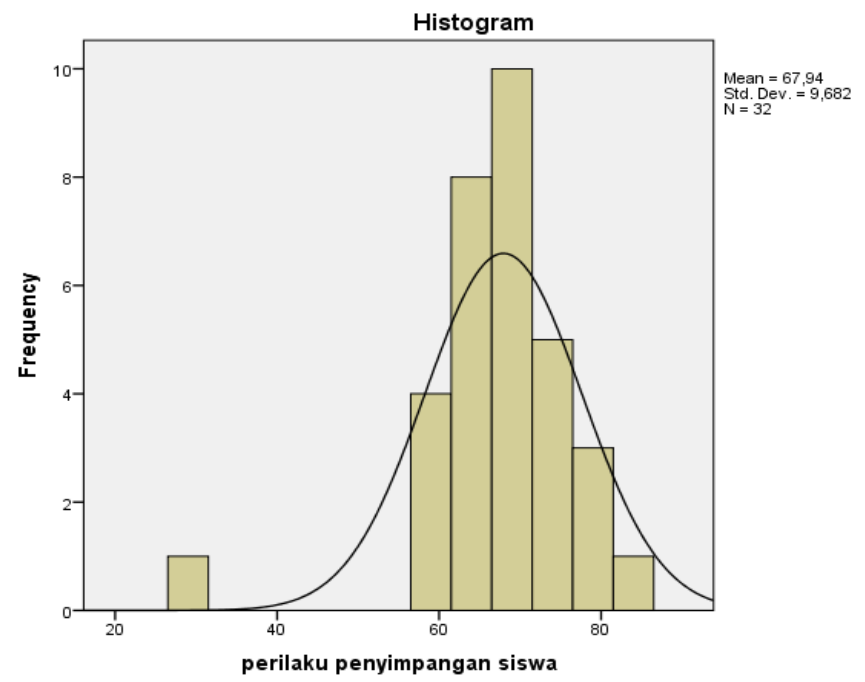

Berdasarkan gambar diatas, menunjukan histogram memiliki bentuk normal, rata-rata histogram terletak ditengah range data. Frekeunsi data paling tinggi di tengah dan menurun secara bertahap dan simetris pada kedua sisina, maka hal tersebut menunjukan bahwa Keluarga Broken Home berdistribusi normal.

\section{b) Uji normalitas}

Uji normalitas Kolmogorov-Smirnov, merupakan uji asumsi klasik. Uji normalitas bertujuan untuk mengetahui apakah nilai residual berdistribusi normal atau tidak. Model regresi yang baik adalah memiliki nilai residual berdistribusi normal. Berikut hasil dari uji normalitas:

TABEL 4.15

HASIL UJI NORMALITAS

One-Sample Kolmogorov-Smirnov Test

\begin{tabular}{|c|c|c|}
\hline & & $\begin{array}{c}\text { Unstandardized } \\
\text { Residual }\end{array}$ \\
\hline $\mathrm{N}$ & & 32 \\
\hline \multirow[t]{2}{*}{ Normal Parameters ${ }^{a, b}$} & Mean & ,0000000 \\
\hline & Std. Deviation & 6,96992802 \\
\hline \multirow[t]{3}{*}{ Most Extreme Differences } & Absolute & ,125 \\
\hline & Positive & 074 \\
\hline & Negative &,- 125 \\
\hline Test Statistic & & ,125 \\
\hline Asymp. Sig. (2-tailed) & & $200^{\mathrm{c}, \mathrm{d}}$ \\
\hline
\end{tabular}

a. Test distribution is Normal. 
b. Calculated from data.

c. Lilliefors Significance Correction.

d. This is a lower bound of the true significance.

Kesimpulan dari tabel 4.17 bahwa hasil dari Uji Normalitas dapat diketahui nilai signifikansi 0,200 >0,05. Maka dengan begitu dapat disimpulkan bahwa nilai residual berdistribusi normal.

\section{c) Uji Linieritas}

Dalam menganalisis uji linearitas, dapat dilakukan dengan dua cara yaitu dengan membandingkan nilai signifikansi (sig) 0,05 dan membandingkan nilai $\mathrm{F}_{\text {hitung }}$ dengan $\mathrm{F}$ tabel. Cara ini digunakan dengan Uji Compare Means dengan menggunakan bantuan Software. Adapun Dasar pengambilan keputusan Uji Linearitas dan nilai $F$ hitung dengan $F$ tabel yaitu:

- Jika nilai Sig Deviation from Linearity $>0,05$, maka terdapat hubungan linear secara signifikan antara variable indefendent dengan variable defendent

- Jika nilai Sig Deviation from Linearity $<0,05$, maka tidak terdapat hubungan linear secara signifikan antara variable indefendent dengan variable defendent

- Jika nilai $\mathrm{F}$ hitung $<\mathrm{F}$ table, maka ada hubungan yang linier secara signifikan antara variabel indefendent dengan variabel defendent

- Jika nilai $\mathrm{F}$ hitung $>\mathrm{F}$ table, maka tidak ada hubungan yang linier secara signifikansi secara linier anatara variabel indefendent dengan variabel defendent. Hasil dari analisis sofware dapat dilihat pada table berikut ini :

TABEL 4.16

HASIL UJI LINEARITAS

ANOVA Table

\begin{tabular}{|c|c|c|c|c|c|c|}
\hline & & $\begin{array}{l}\text { Sum of } \\
\text { Squares }\end{array}$ & Df & $\begin{array}{l}\text { Mean } \\
\text { Square }\end{array}$ & $\mathrm{F}$ & Sig. \\
\hline perilaku Between & (Combined) & 445,208 & 16 & 27,826 & ,320 & ,985 \\
\hline penyim Groups & Linearity & 242,898 & 1 & 242,898 & 2,795 & ,115 \\
\hline
\end{tabular}




\begin{tabular}{|c|c|c|c|c|c|c|c|}
\hline $\begin{array}{l}\text { pangan } \\
\text { siswa * }\end{array}$ & & $\begin{array}{l}\text { Deviation from } \\
\text { Linearity }\end{array}$ & 202,310 & 15 & 13,487 & 155 & 1,000 \\
\hline keluarg & Within Groups & & 1303,667 & 15 & 86,911 & & \\
\hline $\begin{array}{l}\text { broken } \\
\text { home }\end{array}$ & & & 1748,875 & 31 & & & \\
\hline
\end{tabular}

Kesimpulan dari tabel 4.16 diatas menunjukan bahwa hasil Uji linieritas berdasarkan nilai signifikansi dari output diatas, di peroleh nilai Deviation From Linearity sig adalah 1,000 lebih besar dari 0,05, maka dapat di simpulkan bahwa ada hubungan linier secara signifikan antara variabel Keluarga Broken Home (x) dengan variabel Perilaku Penyimpangan Siswa (y).

Adapun berdasarkan nilai $\mathrm{F}$ hitung dengan $\mathrm{F}$ tabel dari output diatas, di peroleh nilai $\mathrm{F}_{\text {hitung }}$ adalah $0,155<\mathrm{F}$ tabel 2,40 . Karena nilai $\mathrm{F}$ hitung lebih kecil dari nilai $\mathrm{F}$ tabel maka dapat di simpulkan bahwa ada hubungan linier secara signifikan antara variabel Keluarga Broken Home (x) dengan variabel Perilaku Penyimpangan Siswa ( y).

Catatan: nilai F tabel di cari dengan rumus (df) Deviation From Linearity ; within groups. Berdasarkan uotput SPPS diatas di ketahui nilai df adalah (15 ; 15). Kemudian di lihat distribusi nilai $\mathrm{F}$ tabel pada signifikansi $5 \%$ atau 0,05 dengan berpedoman pada nlai df tersebut. Maka di temukan nilai $\mathrm{F}$ tabel adalah sebesar 2,40 .

\section{d) Uji Hipotesis variabel}

TABEL 4.17

UJI HIPOTESIS VARIABEL X - Y

Coefficients $^{a}$

\begin{tabular}{|c|c|c|c|c|c|}
\hline \multirow[b]{2}{*}{ Model } & \multicolumn{2}{|c|}{ Unstandardized Coefficients } & \multirow{2}{*}{$\begin{array}{c}\begin{array}{c}\text { Standardized } \\
\text { Coefficients }\end{array} \\
\text { Beta }\end{array}$} & \multirow[b]{2}{*}{$\mathrm{T}$} & \multirow[b]{2}{*}{ Sig. } \\
\hline & $\mathrm{B}$ & Std. Error & & & \\
\hline (Constant) & 110,661 & 17,535 & & 6,311 &, 000 \\
\hline keluarga broken home &,- 524 & ,238 &,- 373 & $-2,200$ & ,036 \\
\hline
\end{tabular}

a. Dependent Variable: perilaku penyimpangan siswa 
Berdasarkan output dari hasil Uji Hipotesis diatas, di ketahui nilai sig variabel (x) keluarga broken home adalah sebesar 0,036. Karena nilai sig $0,036<0,05$ maka dapat di simpulkan $\mathrm{H}_{\mathrm{a}}$ di terima. Artinya ada pengaruh variabel Keluarga Broken Home (x) terhadap variabel Perilaku Penyimpangan Siswa (y). Dan apabila dilihat berdasarkan dari perbandingan dari nilai $\mathrm{t}_{\text {hitung }}$ variabel Keluarga Broken Home dapat di ketahui nilai $\mathrm{t}_{\text {hitung }}$ sebesar 2, 200. karena nilai $\mathrm{t}$ hitung 2,200 $>\mathrm{t}$ tabel 2,0423. Maka disimpulkan $\mathrm{H}_{\mathrm{a}}$ di terima. Artinya ada pengaruh Keluarga Broken Home (x) terhadap Perilaku Penyimpangan Siswa (y).

\section{e) Korelasi dan regeresi}

TABEL 4.18

HASIL KOEFISIEN KORELASI

\section{Correlations}

\begin{tabular}{|ll|r|r|}
\hline & keluarga broken \\
home & $\begin{array}{c}\text { perilaku } \\
\text { penyimpangan } \\
\text { siswa }\end{array}$ \\
\hline keluarga broken home & $\begin{array}{l}\text { Pearson Correlation } \\
\text { Sig. (2-tailed) }\end{array}$ & 1 &,- 373 \\
& $\mathrm{~N}$ & 32 &, 036 \\
perilaku penyimpangan & Pearson Correlation \\
siswa & Sig. (2-tailed) &,- 373 & 32 \\
& $\mathrm{~N}$ &, 036 & 1 \\
& 32 & 32 \\
\hline
\end{tabular}

*. Correlation is significant at the 0.05 level (2-tailed).

Berdasarkan dari hasil analisis korelasi sederhana (r) didapat korelasi antara Keluarga Broken Home terhadap Perilaku Penyimpangan Siswa (r) dengan nilai Koefisien Pearson Korelasi -0,373 > 0,349 ( $\left.\mathrm{r}_{\text {tabel }}\right)$, maka dapat di pastikan ada korelasi yang signifikan (Ha di terima) antara variabel Keluarga Broken Home (x) terhadap Perilaku Penyimpangan Siswa (y). 


\section{f) Uji Signifikansi}

TABEL 4.19

HASIL UJI SIGNIFIKANSI

\begin{tabular}{|c|c|c|c|}
\hline \multicolumn{4}{|c|}{ Correlations } \\
\hline & & $\begin{array}{c}\text { keluarga broken } \\
\text { home }\end{array}$ & $\begin{array}{c}\text { perilaku } \\
\text { penyimpangan } \\
\text { siswa }\end{array}$ \\
\hline keluarga broken home & $\begin{array}{l}\text { Pearson Correlation } \\
\text { Sig. (2-tailed) } \\
\mathrm{N}\end{array}$ & $\begin{array}{r}1 \\
32 \\
\end{array}$ & $\begin{array}{r}-, 373 \\
, 036 \\
32\end{array}$ \\
\hline $\begin{array}{l}\text { perilaku penyimpangan } \\
\text { siswa }\end{array}$ & $\begin{array}{l}\text { Pearson Correlation } \\
\text { Sig. (2-tailed) } \\
\mathrm{N}\end{array}$ & $\begin{array}{r}-, 373 \\
, 036 \\
32\end{array}$ & $\begin{array}{r}1 \\
32\end{array}$ \\
\hline
\end{tabular}

*. Correlation is significant at the 0.05 level (2-tailed).

Uji signifikansi dapat di lihat pada tabel 4.19 dari tabel diatas dapat di lihat bahwa nilai sig. 0,036. Sesuai dengan dasar keputusan yang diambil untuk melihat nilai signifikansi adalah:

- Apabila nilai sig. $<0,05$, maka ada korelasi yang signifikan $\left(\mathrm{H}_{\mathrm{a}}\right.$ diterima)

- Apabila sig. $>0,05$, maka tidak ada korelasi yang signifikan $\left(\mathrm{H}_{0}\right.$ di tolak). Nilai sig.

diatas menunjukkan angka $0,036<0,05$, maka dapat di pastikan ada korelasi yang signifikan ( $\mathrm{H}_{\mathrm{a}}$ di terima). Sehingga dapat di simpulkan bahwa variabel indefenden (Keluarga Broken Home) memiliki pengaruh terhadap variabel defenden (Perilaku Penyimpangan Siswa) sesuai dengan derajat tingkat hubungan dapat di lihat pada tabel di bawah ini:

TABEL 4.20

INTERPRETASI KOEFISIEN KORELASI

\begin{tabular}{|c|c|}
\hline Interval Koefisien & Tingkat Hubungan \\
\hline $0,00-0,20$ & Tidak ada korelasi \\
\hline $0,21-0,40$ & Korelasi rendah \\
\hline
\end{tabular}




\begin{tabular}{|c|c|}
\hline $0,41-0,60$ & Korelasi sedang \\
\hline $0,61-0,80$ & Korelasi kuat \\
\hline $0,81-1,00$ & Korelasi sempurna \\
\hline
\end{tabular}

Berdasarkan nilai pearson korelasinya (negatif) $0,373>0,349 \mathrm{r}$ tabel, maka menjelaskan bahwa derajat hubungan antara variabel Keluarga Broken Home (x) terhadap Perilaku Penyimpangan Siswa (y) berada pada tingkat hubungan 0,21 - 0,40 dengan tingkat hubungannya rendah, sehingga dapat disimpulkan bahwa variabel Keluarga Broken Home memiliki pengaruh negaritf terhadap Perilaku Penyimpangan Siswa.

g) Koefisien Determinasi

TABEL 4.21

HASIL KOEFISIEN DETERMINASI

Model Summary

\begin{tabular}{|l|r|r|r|c|}
\hline Model & $\mathrm{R}$ & $\mathrm{R}$ Square & \multicolumn{1}{c|}{$\begin{array}{c}\text { Adjusted R } \\
\text { Square }\end{array}$} & $\begin{array}{c}\text { Std. Error of the } \\
\text { Estimate }\end{array}$ \\
\hline 1 &, $373^{\mathrm{a}}$ &, 139 &, 110 & 7,08514 \\
\hline
\end{tabular}

a. Predictors: (Constant), keluarga broken home

Berdasarkan output tabel "model summary" di ketahui nilai koefisien determinasi $R_{\text {square }} 0,139$. Nilai $R_{\text {square }} 0,139$ ini berasal dari pengkuadratan nilai koefisien korelasi “ $R$ ” yaitu 0,373 x 0,373=0,139. Besarnya angka koefisien determinasi $\left(\mathrm{R}_{\text {square }}\right)$ adalah 0,139 atau sama dengan 13,9\% . Angka tersebut mengandung arti bahwa variabel keluarga broken home (x) berpengaruh terhadap variabel perilaku penyimpangan siswa (y) sebesar 13,9\%. Sedangkan sisanya $(100 \%-13,9 \%=86,1 \%)$ di pengaruhi oleh variabel lain.

\section{h) Persamaan Regresi}

Secara umum rumus persamaan regresi linier sederhana adalah $\mathrm{Y}=\mathrm{a}+$ bX. Sementara untuk mengetahui nilai koefisien regresi dapat berpedoman pada output yang berada pada tabel berikut: 
TABEL 4.22

PERSAMAAN REGRESI

Coefficients $^{\mathrm{a}}$

\begin{tabular}{|c|c|c|c|c|c|}
\hline \multirow[b]{2}{*}{ Model } & \multicolumn{2}{|c|}{ Unstandardized Coefficients } & \multirow{2}{*}{$\begin{array}{l}\text { Standardized } \\
\text { Coefficients } \\
\text { Beta }\end{array}$} & \multirow[b]{2}{*}{$\mathrm{T}$} & \multirow[b]{2}{*}{ Sig. } \\
\hline & B & Std. Error & & & \\
\hline $1 \quad$ (Constant) & 110,661 & 17,535 & & 6,311 & ,000 \\
\hline keluarga broken home &,- 524 & 238 &,- 373 & $-2,200$ & 036 \\
\hline
\end{tabular}

a. Dependent Variable: perilaku penyimpangan siswa

Dari table 4.22 di jelaskan bahwa $\mathrm{a}=$ Angka Konstan dari Unstandardized Coeffcients nilainya sebesar 110,661. Angka ini merupakan angka konstan yang mempunyai arti bahwa jika ada Keluarga Broken Home (x) maka nilai Perilaku Penyimpangan Siswa sebesar 110,661.

$\mathrm{b}=$ Angka Koefisien regresi nilainya sebesar -,524. Angka ini mengandung arti bahwa setiap penambahan $1 \%$ tingkat Keluarga Broken Home (x), maka Perilaku Penyimpangan Siswa (y) akan meningkat sebesar -,524.

Karena nilai koefisien regresi bernilai minus (-), maka dengan demikian dapat dikatakan Keluarga Broken Home berpengaruh negatif terhadap Perilaku Penyimpangan Siswa (y) sehingga persamaan regresinya $\mathrm{Y}=110,661-0,524 \mathrm{X}$.

\section{Analisis Pembahasan}

Pada bagian analisis pembahasan ini peneliti akan mendeskripsikan semua hasil yang telah di ujikan dalam penelitiannya di lapangan. Peneliti telah melakukan perhitungan dengan bantuan komputer dengan program SPSS versi 23 for windows. Prosentase variable (x) keluarga broken home, Secara empirik hasil analisis perolehan skor angket Keluarga Broken Home, data menunjukan nilai Dengan keterangan Jumlah soal angket 28, Jumlah sample 32, Total perolehan skor 3288, Prosentase 73\%, Rata-rata 73\%, Kategori perolehan skor Baik. Hal ini menunjukkan bahwa keluarga broken home dalam katerogi cukup tinggi. Dengan Ukuran pemusatan dan ukuran penyebaran Tendensi Sentral variabel Keluarga Broken Home. Hasil analisis menunjukan nilai Maksimum 84, Minimum 61, Mean 73,38, Modus 74, Median 74,00, Range 23, Varians 28,500, Standar Deviasi 5,339. Sehingga menghasil grafik 
histogram memiliki bentuk normal, rata-rata histogram terletak ditengah range data. Frekeunsi data paling tinggi di tengah dan menurun secara bertahap dan simetris pada kedua sisina, maka hal tersebut menunjukan bahwa keluarga broken home berdistribusi normal. Adapun Proesntase variable (y) perilaku penyimpangan siswa Secara empirik hasil analisis perolehan skor angket perilaku penyimpangan siswa data menunjukan nilai Dengan keterangan Jumlah soal angket 28, Jumlah sample 32, Total perolehan skor 3230, Prosentase $72 \%$, Rata-rata 72\%, Kategori perolehan skor Baik. Hal ini menunjukkan bahwa perilaku penyimpangan siswa dalam katerogi cukup tinggi. Dengan Ukuran pemusatan dan ukuran penyebaran diperoleh nilai tendensi sentral variabel perilaku penyimpangan siswa. Hasil analisis menunjukan nilai Maksimum 82, Minimum 29, Mean 67,94, Modus 64, Media 68,00, Range 29, Varians 93,738, Standar Deviasi 9,682. menunjukan histogram memiliki bentuk normal, rata-rata histogram terletak ditengah range data. Frekeunsi data paling tinggi di tengah dan menurun secara bertahap dan simetris pada kedua sisina, maka hal tersebut menunjukan bahwa Keluarga Broken Home berdistribusi normal. Sehingga menghasilkan histogram memiliki bentuk normal, rata-rata histogram terletak ditengah range data. Frekeunsi data paling tinggi di tengah dan menurun secara bertahap dan simetris pada kedua sisina, maka hal tersebut menunjukan bahwa Keluarga Broken Home berdistribusi normal.

Adapun melalui perhitungan Uji Noralitas dan Uji Linieritas Variavbel $(x$ dan y). bahwa hasil dari Uji Normalitas dapat diketahui nilai signifikansi 0,200 $>$ 0,05. Maka dengan begitu dapat disimpulkan bahwa nilai residual berdistribusi normal. Kemudian hasil Uji linieritas berdasarkan nilai signifikansi dari output diatas, di peroleh nilai Deviation From Linearity sig adalah 1,000 lebih besar dari 0,05, maka dapat di simpulkan bahwa ada hubungan linier secara signifikan antara variabel Keluarga Broken Home (x) dengan variabel Perilaku Penyimpangan Siswa (y). Adapun berdasarkan nilai $\mathrm{F}$ hitung dengan $\mathrm{F}$ tabel dari output diatas, di peroleh nilai $\mathrm{F}$ hitung adalah $0,155<\mathrm{F}$ tabel 2,40 . Karena nilai $\mathrm{F}$ hitung lebih kecil dari nilai $\mathrm{F}$ tabel maka dapat di simpulkan bahwa ada hubungan linier secara signifikan antara variabel Keluarga Broken Home (x) dengan variabel Perilaku Penyimpangan Siswa ( y). Catatan: nilai $F$ tabel di cari 
dengan rumus (df) Deviation From Linearity ; within groups. Berdasarkan uotput SPPS diatas di ketahui nilai df adalah $(15 ; 15)$. Kemudian di lihat distribusi nilai $\mathrm{F}$ tabel pada signifikansi $5 \%$ atau 0,05 dengan berpedoman pada nlai df tersebut. Maka di temukan nilai $\mathrm{F}_{\text {tabel }}$ adalah sebesar 2,40.

Kemudian melalui perhitungan Uji Hipotesis variable $\mathrm{x}-\mathrm{y}$, output dari hasil Uji Hipotesis di ketahui nilai sig variabel (x) keluarga broken home adalah sebesar 0,036. Karena nilai sig 0,036 $<0,05$ maka dapat di simpulkan $\mathrm{H}_{\mathrm{a}}$ di terima. Artinya ada pengaruh variabel Keluarga Broken Home (x) terhadap variabel Perilaku Penyimpangan Siswa (y). Dan apabila dilihat berdasarkan dari

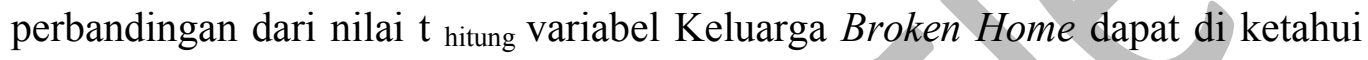
nilai $\mathrm{t}_{\text {hitung }}$ sebesar -2 , 200. karena nilai $\mathrm{t}_{\text {hitung }}-2,200>\mathrm{t}_{\text {tabel }} 2,0423$. Maka disimpulkan $\mathrm{H}_{\mathrm{a}}$ di terima. Artinya ada pengaruh keluarga broken home (x) terhadap perilaku penymoangan siswa (y). Dengan hasil analisis korelasi sederhana (r) didapat korelasi antara Keluarga Broken Home terhadap Perilaku Penyimpangan Siswa (r) dengan nilai Koefisien Pearson Korelasi -0,373 > 0,349 ( $\mathrm{r}_{\text {tabel }}$ ), maka dapat di pastikan ada korelasi yang signifikan (Ha di terima) antara variabel Keluarga Broken Home (x) terhadap Perilaku Penyimpangan Siswa (y) dengan nilai sig. $0,036<0,05$, maka dapat di pastikan ada korelasi yang signifikan $\left(\mathrm{H}_{\mathrm{a}}\right.$ di terima). Sehingga dapat di simpulkan bahwa variabel indefenden ( Keluarga Broken Home) memiliki pengaruh terhadap variabel defenden (Perilaku Penyimpangan Siswa). Dan berdasarkan output "model summary" di ketahui nilai koefisien determinasi $\mathrm{R}_{\text {square }} 0,139$. Nilai $\mathrm{R}_{\text {square }} 0,139$ ini berasal dari pengkuadratan nilai koefisien korelasi " $R$ ” yaitu $0,373 \times 0,373=$ 0,139 . Besarnya angka koefisien determinasi $\left(R_{\text {square }}\right)$ adalah 0,139 atau sama dengan 13,9\% Angka tersebut mengandung arti bahwa variabel keluarga broken home (x) berpengaruh terhadap variabel perilaku penyimpangan siswa (y) sebesar $13,9 \%$. Sedangkan sisanya $(100 \%-13,9 \%=86,1 \%)$ di pengaruhi oleh variabel lain. Dengan Persamaan Regresi di ketahui bahwa : a = Angka Konstan dari Unstandardized Coeffcients nilainya sebesar 110,661. Angka ini merupakan angka konstan yang mempunyai arti bahwa jika ada Keluarga Broken Home (x) maka nilai Perilaku Penyimpangan Siswa sebesar 110,661. b = Angka Koefisien regresi nilainya sebesar -,524. Angka ini mengandung arti bahwa setiap 
penambahan $1 \%$ tingkat Keluarga Broken Home (x), maka Perilaku Penyimpangan Siswa (y) akan meningkat sebesar-,524.

\section{E. Penutup}

\section{Kesimpulan}

Berdasarkan hasil penelitian dan pembahasan yang telah diuraikan sebelumnya, dapat disimpulkan bahwa dalam penelitian ini menunjukan bahwa terdapat adanya hubungan negatif yang signifikan antara keluarga broken home terhadap perilaku penyimpangan siswa di SMP Negeri 2. Keluarga Broken Home di SMP Negeri 2 Plered menunjukan bahwa frekuensi keluarga broken home (X) berada di prosentase $73 \%$, sehingga dapat disimpulkan bahwa keluarga broken home dalam kategori cukup tinggi. Adapun bentuk-bentuk perilaku penyimpangan yang di timbulkan Siswa di SMP Negeri 2 Plered, seperti halnya membolos, datang terlambat, tidak pernah memperhatian guru, tidak mengerjakan tugas, kepada guru tidak sopan, suka melawan, dikelas selalu bikin rusuh, suka mengganggu teman, caper, suka jalan-jalan di kelas atau sebentar-bentar minta izin keluar ke kamar kecil, suka berkelahi, suka memanjat tembok sekolah, meminta uang pada teman secara paksa, menunjukan pada prosentase sebesar $72 \%$ maka dapat disimpulkan bahwa perilaku penyimpangan siswa di SMP Negeri 2 Plered dalam kategori cukup tinggi. Adapun pengaruh keluarga broken home terhadap perilaku penyimpangan siswa di SMP Negeri 2 Plered, terdapat pengaruh negatif dan signifikan antara variable keluarga broken home $(x)$ terhadap perilaku penyimpangan siswa $(y)$ Berdasarkan nilai pearson korelasinya (negatif) $-0,373>0,349 \mathrm{r}$ tabel, maka menjelaskan bahwa derajat hubungan antara variabel Keluarga Broken Home $(x)$ terhadap Perilaku Penyimpangan Siswa (y) berada pada tingkat hubungan 0,21 0,40 dengan tingkat hubungannya rendah dengan persentase hubungan sebesar $13,9 \%$. sisanya $86,1 \%$ di pengaruhi oleh variabel lain.

\section{Saran}

Berdasarkan pada hasil penelitian dan fakta yang penulis peroleh, maka penulis dapat memberikan saran bagi semua pihak yang berorientasi didalam dunia pendidikan umumnya dan khususnya di SMP Negeri 2 Plered sebagai berikut:

1. Bagi peneliti selanjutnya untuk mengetahui lebih dalam tentang pengaruh keluarga broken home terhadap perilaku meyimpang siswa di SMP Negeri 2 Plered 
2. Bagi lembaga sekolah, diharapkan penelitian ini menjadi masukan efektif dan efesien dalam menangani kasus pengaruh keluarga broken home terhadap perilaku peyimpangan siswa di SMP Negeri 2 Plered

3. Bagi guru BP ataupun guru pengajar dikelas diharapkan lebih peka terhadap kondisi pisik dan psikis peserta didik di sekolah dan dapat memberikan pelayanan lebih seperti motivasi dan bimbingan lebih kepada peserta didik.

4. Bagi orang tua, dengan adanya penelitian ini diharapkan dapat untuk lebih sempurna dalam memberikan kasih sayang dan perhatian kepada anakanaknya .

\section{DAFTAR PUSTAKA}

Hasbullah. 2011. Dasar-Dasar Ilmu Pendidikan. Jakarta : PT Raja Grafindo Persada

Sofyan Willis, S., 2017. Konseling Keluarga (Family Counseling). Bandung : Alfabeta

Kartono Kartini. 2013. Patologi Sosial 2: Kenakalan Remaja, Jakarta : PT Raja Grafindo Persada

Ulfiah. 2016. Psikologi Keluarga. Bogor : Ghalia Indonesia

Al Qur'an Surat Al Ahzab ayat 21

Soelaeman, M.I., 1978. Pendidikan dalam Keluarga. Bandung : Bhumi

Siliwangi

Yusuf, Syamsu. 2011. Psikologi Perkembangan Anak dan Remaja. Bandung :PT Remaja Rosdakarya

Sudarsono. 2015. Kenakalan Remaja. Jakarta : PT Rineka Cipta

Pujileksono, Sugeng. 2018. Pengantar Sosiologi. Malang : Intrans

Publishing

Arikunto, Suharsimi. 2010. Prosedur Penelitian. Jakarta: PT. Rineka Cipta

Sugiyono. 2009. Metode Penelitian Pendidikan, Pendekatan Kuantitatif, Kualitatif, dan R\&D. Bandung : Alfabeta

Hanik, Ummi. 2018. Peran Guru Bimbingan Konseling dalam Mengatasi Kenakalan Siswa Korban Broken Home di SMK MA'ARIF NU 1 
Wonolopo Kecamatan Mijen Kota Semarang, Skripsi. Semarang : Universitas Islam Negeri Walisongo

Aziz, Mukhlis, 2015. "Perilaku Sosial Anak Remaja Korban Broken Home dalam berbagai Perspektif," : Jurnal Al Ijtimaiyyah, Vol. 1, No. 1

Sayidatun Nisya, Lidya, dan Sofiah, Diah, 2012. "Religiusitas, Kecerdasan Emosional dan Kenakalan Remaja," : Jurnal Psikologi, Volume. 7, No. 2

Primadha,Risjad,PerilakuMenyimpangSiswaSMP, file:///C:/Users/ASUS/Do wnloads/toeri\%20keluarga\%20broken\%20dan\%20perilkau\%20penyi mpngan/indikator\%20penyimpangan.pdf, Diakses pada 15 April 2020

Elisa Jelita, Sinta., Definisi Perilaku Menurut Kamus Besar Bahasa Indonesia adalah Tanggapan Atau Reaksi, https://id.scribd.com/doc/21746354/definisi-perilaku-menurut-kamusbesar-bahasa-indonesia-adalah-tanggapan-atau-reaksi. Diakses pada 24 februari 2020

Prasetyo,Vendi,pengertianbrokenhomehome,http://sobatbaru.blogspot.com/2 008/04/pengertian-broken-home.html. diakses pada 7 maret 2020 